I had just risen to speak to him, but before I could do so, a loud rumbling sound seemed to come on my right hand (or from the direction of the Kulu Valley).

One of the party called out thun-we had had a thunderstorm the day before-but changed the word to earthquake. For a second or two I held my breath-I felt rooted to the spot; then the permanent wooden balcony over my hea $t$ bexan to creak and grual most violently, and I distinctly saw the front wall of the hou,e advance towards me, and recede from me, three or four time:

After the motion hat ceased, the rumbling sound, which at its ge eatest intensity seemed beneath our feet, died away in the opposite direction (or towards Simla). I made many inquiries afterwards, but was unable to ascertain whether any shocks of earthquake had been experienced on these dates either in Kulu in 1878 or in Lahoul or at Simla in 1881 .

The recent catastrophe in the Islaud of Ischia has called the attention of those who make a study of such disturbances of the earth's sufface to the simultaneou; occurrence of earthquakes in varions parts of the world, which induces me to send you these facts, in the hope that they may interest some of your readers and lead them to form some conjecture as to the possible centre of the earthquakes in the Himalayas.

I am not aware to what extenc the geological formation of the Himalayas has been-investigated, but (speaking as a non-profes. si mal) during three long tours in various parts of these mountaius I have never observed any traces of extinet volcanoes. I uught, however, to mention, perhaps, that there are hot springs $a^{+}$seshist on the left bank of the Beas River, about four miles fr $m$ Mañali, and also at Manikern, in the Parbuti valley, which debouches from the Kulu valley, about thirty miles lower down, also on the left bank of the river. Manikern is a great pl:ce of resort for Hindu pilgrim, who consider these hot springs miraculous; it is also occasionally visited by Europeans who have found these waters efficacious in rheumatic affections. Earthquakes do not seem to be uncommon in these valleys, but it has been remarked that they generally, if not always, occur in the autumn, just when the rainy season $i_{i}$ at an end.

COSMOPOLITAN

\section{Lime and Bones}

THE observation of your correspondent in NATURE, vol. xxviii. p. 329 , regarding the effect of time in stren thening the bones of children, indaces me to communicate cerlain tacts which I observed during a recent tour of two months in Norway.

We travelled by land from Christiania to Throndhjem, thence by sea to the North Cape and back, and made expeditions into the interi $r$ at different points on our downward journey.

I noticed everywhe:e an extraordinary number of weakboned, crippled, and bandy legged children, also a great number of men and women with weak bones and distorted limbs.

Almost the whole of Norway is a network of mountains composed of various forms of primitive and metauorohic rock, and thou gh marble exists in this country 1 saw none in the districts through which we passed.

Christiania, August II

\section{Copper and Cholera}

REFERRING to the paper read before the French Academy (as reported in your last issue) on copper as a preservative against cholera, it may be worth while to state that when visiting the great copper mines at Fahlun in sweden (probably the oldest and largest in the world) I was informed that cholera had never appeared there, and that so well was the fact known that on the last visitation of cholera in sweden some members of the Royal family took up their abode in Fahlun to escape the disease. The atmosphere was there loaded with copper fumes to such an extent that not a trace of vegetation was visible on the hills surrounding the town; so that this really seems to confirm by experience on a large scale the theory alluded to.

WALter R. Browne

\section{Sulphur in Bitumen}

From the abstract of the meeting of the Paris Academy of Sciences in your last number (vol, xxviii. p. 408), M. B. Dela. chanal appears to consider that the presence of sulphur is peculiar to the bitumen of the Dead Sea, and from this he deduces a theory as to its inorganic origin.

In some experiments which I had occasion to make this summer on the bitumen of the Great Pitch Lake of Trinidad I found that this substance contained a very considerable quantity of sulphur. Several per cents. of the volume of the gas obtained by its destructive distillation consisted of hydrogen sulphide. The origin of this asphait is generally considered to be organic, but I am not aware whether the entire absence of calcium salts from its ash, a fact which was proved nearly a century ago, and has since been confirmed, has been explained on this theory.

Edinburgh, Angust 27

\section{Thunderstorms and Auroræ}

A CONNECTION between these phenomena has been repeatedly suggested. J. W. Ritter has articles on the subject in Gilbert's Annalen (1803 and 1804), and Kupffer has a long one in 1827 . Other writers who have dealt with it or with the connection between aurore and atmospheric electricity generally are Schüble (I8I7), R. Phillips (1854), F. Dellmann (1860), E. Loomis (1860, 186r, and 1862), A. Poey (1861), A. De la Rive, F. Abbott (1863), E. Edlund; and in NATURE, vol. xii. p. I27, there is a summary of the observations by Herr von Bezold, This may serve as a parial answer at the end of Mr. Chadbourn's letter.

4, Cowper Road, Acton, W., August 27

A. RAMSAY

\section{The Meteor of August ig}

THE details of this meteor in the letter of your correspondent Mr. Mott and my own are for the most part in such close acc.rdance that one might suppose we bad been comparing notes. There is, however, one particular in which our respective accounts differ so widely that one feels inclined to ask whether there were two meteors or whether one of your correspondents has made a mistake as to the direction of the course of the meteor.

First let me correct an error of my own. I find now I was wrong in giving the point of starting as a few degrees eastward of the north star. I am somewhat of a stranger at the place where I saw it, and I now find that the point from which it started was as nearly as possible north-east, and about $65^{\circ}$ or $70^{\circ}$ above the horizon.

I am quite clear as to the path being downwards in an almost perpendicular direction inclining a little to the left. Mr. Mott, on the other hand, deccribes it as " nearly horizontal, inclined a little downwards about $10^{\circ}$ or $12^{\circ}$ above the horizon, apparently much foreshortened." It appear's to me-perhap; owing to a want of scientific knowledge-quite impossible that a meteor visible a few miles sonth-west of London, falling as I have described, could be identical with one seen two hundred miles north-west of London travelling in the direction described by Mr. Mott. $l$ of course lay the stress on the direction of the meteor and not the distances of the observers from London.

Lancdowne Road, Wimbledon, s. W., August 27

IT may be of interest to some of your readers to know that the meteor mentioned in NATURE as seen on Sunday evening, August 19, was al-o seen here, timed by me at Io. I p.m. 'The compass bearings were from sonth-east past east to east-eastnorth, about $35^{\circ}$ from horizon ; colour, yellow orange; first seen coming from behind a cloud; clivided due east, one part falling considerably.

Bath Road, Cheltenham, August 26

\section{Stachys palustris as Food}

I SHOULD be much obliged if any of your readers could give me any information as to whether the rhizomes of Stachys palustris, I., are used by the country people either in Great Britain ur elsewhere for food. I believe the English name of the plant is Base Horehound, and that in the last century it was so uscd. A. WENT7'I

Krásnicza Wola, Grodzisk, near Warsaw, August is 